\title{
6. The emergence of transnational hybrid governance: how private risks trigger public intervention
}

\author{
Johannes Karremans and Adrienne Héritier
}

\subsection{INTRODUCTION}

The wave of financial market regulations that followed the financial crisis of 2008 offers new insights for understanding the conditions under which public regulators intervene in privately self-regulated markets and the possible forces containing their actions. The legislative and regulatory initiatives that were taken in the EU between 2009 and 2018, in fact, extended the reach of public regulation into areas that were previously mostly regulated through privately set standards. However, as the new rules and regulations do not affect all aspects of the financial markets in the same way, they provide a considerable degree of within-case variation in terms of the extent to which certain segments of the market are affected by - or remain exempt from - the extension of public oversight. This within-case variation is highly useful in providing a deeper insight into whether - and under which conditions - private self-regulation prompts (centralised) public regulation (H8). In this chapter, by investigating the interaction between private and public regulators during the post-crisis regulatory wave, we probe the plausibility of our hypotheses about how systems of hybrid governance emerge and develop.

As anticipated in Chapter 1 (section 1.3), with regard to the emergence and development of systems of hybrid regulatory governance, we expect a sequence of two different causal mechanisms. First, our expectation is that systems of private self-regulation develop together with the emergence of new market instruments (H8.1) and that private self-regulatory regimes will attract new market actors who will abide by their existing norms and procedures (H8.2). Second, systems of hybrid governance develop in a subsequent stage and largely rely on the existing structures of the private regimes, but with some surveillance by public actors. More specifically, we expect there to be two conditions under which public authorities may decide to intervene in a private 
regulatory regime, thereby creating a mixed public-private system of governance. The first of these conditions (H8.3) is that key players in the private regulatory regime are excessively rent-seeking, thereby damaging market players, customers and consumers. The second condition (H8.4) is that the segment of the market that is privately self-regulated may create system-stability risk, thereby calling for a centralised regulatory structure. Given the interlinkedness of financial transactions worldwide, the first condition of excessive rent-seeking may enhance the second condition of system-stability risk if new financial-instrument markets are important enough in terms of volume.

In this chapter, we probe the plausibility of our argument by looking at two cases that differ substantially in the extent to which they have been affected by the post-crisis regulatory wave. These are: (a) the international over-the-counter (OTC) derivative market; and (b) the Alternative Investment Market (AIM) of the London Stock Exchange. Both markets emerged and developed with private self-regulation. However, the extent and the timing with which public regulators sought to extend their control over them varied greatly. OTC derivative markets, in fact, came under the spotlight immediately at the G20 Pittsburgh summit in September 2009. The AIM, by contrast, remained largely untouched by European legislation until 2016. In two in-depth case studies, we describe the private self-regulatory regimes that were put in place in these two markets and analyse how these regimes have been affected by public regulatory initiatives. In the analysis, we explore the interaction between public authorities and the dominant private actors operating in the markets.

For the case of OTC derivative markets, we start by describing how the International Swaps and Derivatives Association (ISDA) was the private authority regulating these markets between the 1980s and 2008, and how in the aftermath of the global financial crisis public regulators started to coordinate their actions at the international level to fill the regulatory gaps in the markets. Subsequently, by means of a policy document analysis, we show how ISDA tried to shelter certain segments of the OTC market from the Commission's regulatory initiatives. The case study thus provides an illustration of how ISDA tried to influence EU regulatory initiatives and sketches the mix of private and public responsibilities in the current regulatory framework. As we shall see, in the new hybrid governance framework, the regulatory quasi-monopoly that ISDA used to have until 2012 has substantially been curbed by the central clearing obligations introduced by the European Market Infrastructure Regulation (EMIR). At the same time, however, ISDA maintains an important authority not only over those derivatives that are exempted from central clearing, but also in the definition of the technical terms under which those exemptions apply. 
For the case of the AIM, we start by describing how this market was purposefully established in 1995 to allow small companies to bypass the compliance costs related to British and European legislation, and how it developed a light-touch but controversial regulatory regime. We proceed by examining how an accumulation of malpractices and a record of relatively low returns for investors gradually triggered the attention of public regulators, which, however, limited themselves mostly to pressing the private regulators to monitor misconduct more closely. Subsequently, we show how companies listed in the AIM became directly subject to European transparency rules in 2016, which, however, did not alter the fundamental functioning of the existing regulatory regime. In the case of the AIM, the hybrid regime features limited public intervention and large elements of continuation from the previous private regime.

We conclude the chapter with an assessment of whether these two cases confirm our argument that when market participants are excessively rent-seeking and/or there is potential systemic risk private self-regulation eventually develops into a hybrid system of governance, with public authorities trying to centralise regulation which is, however, based on the existing structures of the private regime.

\subsection{THE NEW HYBRID GOVERNANCE OF OTC DERIVATIVE MARKETS}

\subsubsection{The Emergence of a New Market and its Private Regulation}

OTC derivatives constitute a particular sector of the financial market. Backed also by the rise of neoliberal ideas about the benefits of unregulated markets (Mügge 2011), between the 1980s and 2000s they "operated largely within a regulatory vacuum" (Awrey 2010, p. 162). This lack of public regulation was strongly related to the nature of OTC derivatives. Like all other derivatives, these instruments derive their value from another underlying asset (Flanagan 2001) and can therefore be defined as being "nothing more than probabilistic bets on future events" (Stout 2011, p. 304). They include contracts representing the right (and sometimes the obligation) to buy or sell a certain security, commodity, currency or "another financial instrument at some future date at a predetermined settlement rate" (Biggins and Scott 2012, p. 312). Unlike exchange-traded derivatives, however, OTC derivatives are traded 'over-the-counter', directly between buyers and sellers, and therefore do not pass through a central clearing counterparty (CCP) that interposes itself between the buyer and the seller. They are therefore traded via ad hoc agreements between buyers and sellers. Consequently, they are typically more tailor-made for end-users and less standardised. As a result, they are on the one 
hand considered useful risk management and investment strategies while on the other they are also considered to be riskier than derivatives traded through a CCP (Biggins and Scott 2012, p. 316).

While trades in these types of instrument can be traced back as far as the fifteenth century, the internationalisation of the financial market in the 1980s and the related growth in the use of advanced computer technologies transformed financial markets, and OTC derivative markets came to stand at the centre of modern banking (Schinasi et al. 2000). In this transformation, OTC derivatives became increasingly complex instruments involving multiple payment exchanges, with credit exposures being increasingly associated with time-varying derivatives (Schinasi et al. 2000, pp. 3, 16). Consequently, the flows of liquidity associated with OTC derivative transactions became more difficult to understand and predict, even for experts in the sector. With advanced computer technologies, both the volume and the speed of trades in these instruments increased exponentially (Schinasi et al. 2000). Within just two decades, OTC derivatives became the world's biggest market (Helleiner et al. 2018) and, despite bearing considerable systemic risk, they remained sheltered from public regulation. This shelter was partially provided by the complexity of the market and partially by the private interest group that asserted itself as a private regulatory authority: the International Derivatives and Swaps Association (ISDA).

Ever since its foundation in 1985, ISDA has largely focused its activity on establishing itself as a private actor that ensures stability and predictability in the trading of swaps and derivatives, and in particular of OTC derivatives (Morgan 2008). In the thirty years between the rise of international derivative markets in the 1980s and the financial crash of 2008, ISDA developed a system of private self-regulation in derivative markets that ensured standard practices of derivative trading, providing contractual standards and facilitating transactions. Amongst these, the most important accomplishment was the establishment of a Master Agreement whereby market participants can rely on a standard contract to trade in derivatives. Because of their bespoke nature, at the time of their emergence OTC derivatives lacked a common 'language'. As this shortcoming hampered the expansion of the market, ISDA filled the vacuum by setting standards at which contracts on a global scale could be developed (Rauterberg and Verstein 2013). ISDA's Master Agreement, consequently, became the global standard for trading OTC derivatives and strengthened the association's authority in the eyes of public regulators, and also the idea that the OTC derivative market worked best if self-regulated. ${ }^{1}$ In parallel, ISDA played a double guarantee role: towards public regulators it stood as a guarantor of system stability, whereas towards buyers and sellers it facilitated the settling of outstanding obligations. The case of the Lehman Brothers Bank collapse in 2008 is emblematic, as within a week of the collapse 
all OTC contracts referencing the bank were settled thanks to ISDA's services (Morgan 2009, p. 33).

The establishment of ISDA as a private regulatory authority was in line with the idea that systems of private self-regulation develop together with the emergence of new market instruments (H8.1). Even though the practice of OTC derivative trading existed long before the establishment of ISDA, the complexity of the instruments that progressively entered the financial markets in the 1980s was unforeseen. ISDA emerged as an authority that would regulate trading in these complex derivatives and provide common standards internationally. This happened in spite of the growing market share of OTC derivatives and their potential systemic risk. Even though on various occasions trading in OTC derivatives led to big financial losses for high-profile market participants - like Procter \& Gamble in 1994 - these risks did not trigger public intervention. On the contrary, such incidents generally resulted in strengthening ISDA's role as a standard-setter and even as an educator of market participants (Flanagan 2001, pp. 224-225).

This brings us to our second hypothesis on the development of private self-regulatory regimes (H8.2), namely that they will attract new market participants who will in turn abide by the rules put in place by the existing regulatory regime. This hypothesis finds confirmation not only in the role ISDA played in the market between the 1980s and 2008 but also in the rapid growth and the organisation of its membership. Having been founded by 11 financial institutions, ISDA grew to have 500 members at around the turn of the century and over 900 today, including the world's biggest banks, financial operators and large corporations. It is interesting to note that the members are organised in different categories according to their role in the market: banks dealing in derivatives are Primary Members, service providers that play a key role in the functioning of the market are Associate Members, and end-users are Subscribers. With this organisational structure, ISDA thus provides a forum for all market participants to discuss the rules governing the private regulatory regime. In this forum, however, only the Primary Members develop ISDA's self-regulatory policies and have the final say on the policy-advocacy strategies of the organisation. Table 6.1 illustrates ISDA's organisational structure. The primary members are thus the world's most important commercial banks, most of which have been recognised as having the status of global systemic important banks by international public authorities such as the Financial Stability Board. ${ }^{2}$ In parallel, many important public institutions like the European Investment Bank and the European Stability Mechanism are among the Subscriber Members. This is indicative of how a privately born institution like ISDA grew to attract public authorities, which in some cases - like for example the Bank of Italy - even became end-users of the financial instruments sold by ISDA's Primary Members (see also Lagna 2016). 


\section{Table 6.1 ISDA's organisational structure}

\begin{tabular}{|c|c|c|c|}
\hline & Primary Members & Associate Members & Subscriber Members \\
\hline Number & 208 & 311 & 417 \\
\hline Description & $\begin{array}{l}\text { Main global and } \\
\text { international dealers of } \\
\text { derivatives }\end{array}$ & $\begin{array}{l}\text { Service providers, i.e. key } \\
\text { components of the derivative } \\
\text { market infrastructure, } \\
\text { including exchanges, } \\
\text { clearing organisations and } \\
\text { repositories, as well as law } \\
\text { firms, accounting firms and } \\
\text { technology solution providers }\end{array}$ & $\begin{array}{l}\text { End users, i.e. } \\
\text { corporations, financial } \\
\text { institutions, government } \\
\text { entities and others that } \\
\text { use derivatives to better } \\
\text { manage financial risks }\end{array}$ \\
\hline Function & $\begin{array}{l}\text { To participate in } \\
\text { policy-development and } \\
\text { advocacy }\end{array}$ & $\begin{array}{l}\text { To stay up to date with } \\
\text { and influence important } \\
\text { developments and initiatives }\end{array}$ & $\begin{array}{l}\text { To stay up to date with } \\
\text { and influence important } \\
\text { developments and } \\
\text { initiatives }\end{array}$ \\
\hline Examples & $\begin{array}{l}\text { ABN AMRO Bank N.V., } \\
\text { Banca Monte Dei Paschi } \\
\text { di Siena SpA, Barclays, } \\
\text { Deutsche Bank AG, } \\
\text { Goldman Sachs \& Co., } \\
\text { Intesa Sanpaolo SpA, } \\
\text { JPMorgan Chase \& Co., } \\
\text { Lloyds Banking Group } \\
\text { Plc, Morgan Stanley \& } \\
\text { Co. International plc, } \\
\text { Royal Bank of Canada }\end{array}$ & $\begin{array}{l}\text { Accenture AG, Bloomberg } \\
\text { Financial Markets, Chicago } \\
\text { Board Options Exchange, } \\
\text { Deloitte LLP, Ernst \& } \\
\text { Young, Eurex Clearing AG, } \\
\text { KPMG LLP, NASDAQ } \\
\text { OMX Stockholm AB, Satori } \\
\text { Consulting, Thomson Reuters }\end{array}$ & $\begin{array}{l}\text { African Development } \\
\text { Bank, Banca d'Italia, } \\
\text { Bank of England, } \\
\text { Eurasian Development } \\
\text { Bank, European } \\
\text { Investment Bank, } \\
\text { European Stability } \\
\text { Mechanism, Intel } \\
\text { Corporation, McDonald's } \\
\text { Corporation, Vodafone } \\
\text { Group Services Ltd. }\end{array}$ \\
\hline
\end{tabular}

Note: Information retrieved from: https://www.isda.org/membership (accessed 12 September 2019).

The intermingling of the private and public spheres, in turn, is not limited to the use of derivatives by public institutions, but there is also a dependence of private regulatory entities on the enforcing hand of public authorities. As argued earlier, financial contracts rely on private law but - in the case of liquidity crises - they need the guarantee of a central public authority (Pistor 2013). Consequently, private regulators need to engage with public authorities. Therefore, in addition to its self-regulatory activity, since its foundation ISDA also actively engaged in lobbying national governments to make sure that their legislation - particularly in the field of insolvency and bankruptcy - was in harmony with the standards of the Master Agreement. More specifically, ISDA was particularly active in ensuring that OTC derivative transactions remained outside the realm of bankruptcy and gambling legislation (Biggins and Scott 2012). Thus, ISDA ensured that the parties to a derivative exchange would be 
able to smoothly net out their balances even in the case of the bankruptcy of one of the parties without going through the legal procedures associated with national bankruptcy legislation. Consequently, ISDA also devoted a considerable part of its activity to ensuring that netting (i.e. the clearing of a contract with one single payment combining various streams of payments) was in line with national legal codes (Morgan 2008, pp. 647-651).

Aware of its dependence on the enforcing hand of public authorities, ISDA worked in close collaboration with national governments, which in turn welcomed the expertise provided by market participants. ISDA and public legislators shared an interest in the stability of the financial system. Public legislators therefore trusted the advice of private experts on the most appropriate legislation for the market to function, while the private sector needed a harmonisation of legislation in different national jurisdictions to favour market transactions. In its lobbying activity, ISDA mainly succeeded in leaving derivative markets outside the scope of bankruptcy and gambling laws and also in promoting netting legislation in different countries (Morgan 2008; Biggins and Scott 2012). On a broader scale, the main success of ISDA was probably its capacity to frame how derivative markets were talked and thought of in the public sphere (Morgan 2008, p. 640). Like other business associations, ISDA in fact succeeded in promoting a narrative on the social and economic desirability of derivative markets (Morgan 2008; Bowman et al. 2017; Engelen 2017).

These interactions with public authorities suggest that the possibility of a shift towards a hybrid public-private system of governance was already present in the heyday of ISDA as a private regulatory authority. The interactions between ISDA and public authorities, however, were not triggered by the potential systemic risk in the derivative market or by excessive rent-seeking activities by market participants. Instead, these interactions were the result of a need for the public authorities' enforceable hand, a feature that the private regulatory regime lacked. This suggests that private regulatory regimes are always - at least to some small degree - hybrid, in the sense that the private regime needs the recognition and sometimes even the collaboration of a public authority (Pistor 2013) (see Chapter 1 in this volume). In the case of the OTC derivative market, however - up until 2008 - the interactions and collaborations between private and public authorities were generally not initiatives by the latter but instead by the ISDA, aimed at strengthening the enforceability of its contractual standards (Morgan 2008).

This all changed with the global financial crisis of 2008, when the global financial system came close to collapse and public regulators were forced to step in. For the OTC derivative market, this meant an end to almost three decades of being sheltered from public regulation. For ISDA, it meant that probably for the first time it was not taking the initiative in its exchanges with public legislators but instead was forced to react to the latter's initiatives. 


\subsubsection{Public Intervention and the Establishment of a Hybrid Governance Regime}

Following the fall of Lehman Brothers and the consequent financial crisis, between 2008 and 2009 the G20 leaders intensively coordinated their actions to remedy the lack of regulation in the financial market sector. In their common statement after the 2009 Pittsburgh summit, the G20 leaders underlined their commitment to improving and expanding the scope of public regulation and supervision. ${ }^{3}$ This commitment particularly regarded OTC derivatives, which were identified as being at the heart of what went wrong during the financial crisis. ${ }^{4}$ The package of measures that leaders agreed upon was presented as an effort to tackle excessive risks taken by large global financial firms, like, for example, in the following passage:

We committed to act together to raise capital standards, to implement strong international compensation standards aimed at ending practices that lead to excessive risk-taking, to improve the over-the-counter derivatives market and to create more powerful tools to hold large global firms to account for the risks they take. Standards for large global financial firms should be commensurate with the cost of their failure. For all these reforms, we have set for ourselves strict and precise timetables. ${ }^{5}$

In the statement, references to the OTC markets always mentioned the excessive risk taken by financial firms. Consequently, the statement presented a number of measures to be implemented by the members of the G20 by the end of 2012. The following passage from the statement indicates the type of measures the G20 leaders agreed on with regard to the OTC derivative market:

Improving over-the-counter derivatives markets: All standardised OTC derivative contracts should be traded on exchanges or electronic trading platforms, where appropriate, and cleared through central counterparties by end-2012 at the latest. OTC derivative contracts should be reported to trade repositories. Non-centrally cleared contracts should be subject to higher capital requirements. We ask the FSB and its relevant members to assess regularly implementation and whether it is sufficient to improve transparency in the derivatives markets, mitigate systemic risk, and protect against market abuse. ${ }^{6}$

The statement explicitly refers to the public regulation of the OTC derivative market as a necessary action to 'mitigate systemic risk' and 'protect against market abuse'. The systemic risk associated with OTC derivatives would later also be underscored by the FSB, which ascribed systemic importance to the large numbers of global financial firms dealing in these instruments. ${ }^{7}$ The excessive rent-seeking behaviour and market abuses, in turn, were underscored by the numerous cases of disproportionately high bonuses for managers of financial firms dealing in OTC derivatives (e.g. The Telegraph 2009). 
As is also discussed in Chapter 3 by Fabio Bulfone and Agnieszka Smoleńska, in Europe the G20 commitments to reform the regulation of the OTC derivatives market translated into the establishment of the European Market Infrastructure Regulation (EMIR) in 2012. The central-clearing and reporting obligations introduced by EMIR can therefore be considered the European extension of the commitments made by the G20 leaders at the 2009 summit in Pittsburgh to tackle excessive risk-taking behaviour by global financial firms. ${ }^{8}$ The sequence of events therefore followed the logic of our argument: public authorities step into privately self-regulated markets when they perceive key market players to be becoming excessively rent-seeking (H8.3) and when a failure to regulate their activities can cause serious systemic risk (H8.4).

At the same time, however, the introduction of European regulation also involved a considerable amount of power politics between member states, with some countries favouring a more light-touch regulation and others strong public intervention (Quaglia 2012). As a result, while EMIR was drafted at the European level, its implementation runs the concrete risk of featuring patterns of de-centralisation, with different countries performing different modalities of market supervision (Helleiner 2014; see also Chapters 2 and 3 in this volume). Nonetheless, in terms of rule-making, EMIR can be considered an effort to centralise regulatory authority at the European level. Under the new regulatory framework, in fact, European institutions such as the European Securities and Markets Authority (ESMA) not only have the authority to decide on the criteria OTC derivatives need to comply with the new reporting and clearing obligations but also have the competence to authorise trade repositories (TRs) and CCPs, which under EMIR have become key players in the derivative market. Following our hybrid governance research perspective, we are interested in exploring how ISDA positioned itself with regard to both the content of the regulation and the centralisation of rule-making.

Thanks to its expertise in the functioning of these markets, ISDA remained a powerful interlocutor for governments and public authorities. For example, ESMA's first chair, Steven Maijoor, gave his first public speech at an ISDA conference $^{9}$ and in the speech reasserted the public regulators' view of OTC derivatives as carriers of risk and underscored the market's systemic importance. At the same time, the chairman also acknowledged ISDA's contributions helping to improve the market's resilience. The following passages report Steven Maijoor's statements in this regard:

The financial crisis we have faced and whose effects are still felt very seriously has no single cause. However, the structure and functioning of the OTC derivatives markets played a major role in amplifying and spreading the risks entrenched in 
the financial market by creating an opaque web of interdependencies difficult to understand and disentangle. [...]

While we all still recognise the importance of OTC derivatives, we have also become more aware of their limitations and risks. Collective efforts are under way to make these markets safer.

The industry, in particular ISDA and the major market participants involved in its activities, have worked to improve the resilience of the OTC derivatives markets by signing and delivering upon important commitments. The fact that we now have CCPs clearing OTC derivatives and trade repositories recording the majority of transactions in certain asset classes is largely due to the efforts of the industry although the supervisors have also played a role in guiding those developments. ${ }^{10}$

ISDA, therefore, did not seem to oppose the initiatives towards central clearing and reporting obligations, but instead promoted itself as the sectoral interlocutor for developing measures that would ensure system stability. In fact, ISDA started expressing favourable positions towards central clearing as early as October 2008 in a letter to the American Federal Reserve, ${ }^{11}$ and maintained these positions in the following years. In the run-up to EMIR, ISDA regularly released policy documents in which it took positions on the EU's legislative initiatives regarding OTC derivative markets. ${ }^{12}$ These documents were often responses to consultation papers released by the European authorities. ${ }^{13}$ In these exchanges, ISDA confirmed its support for a regulatory framework that was common to all EU member states and that followed the broader initiative taken at the global level by the G20 leaders.

Moreover, this development was very much in line with ISDA's traditional goal of developing common standards for market participants. In addition, ISDA found itself in a favourable position to influence regulatory initiatives. In fact, the extension of public oversight - and particularly of central clearing obligations - required an assessment of the eligibility of specific derivatives for central clearing. Consequently, public regulators needed the advice of market insiders to establish such eligibility criteria and ISDA became one of the main interlocutors (Biggins and Scott 2012, p. 340). The following quotation offers an insight into how ISDA filled this role. The passage is taken from a comment paper of July 2011 in which ISDA commented on the collateral requirements for derivatives to be cleared through CCPs.

Given the importance of this issue, and its technical nature, we favour a solution whereby the European Securities and Markets Authority (ESMA) is tasked with producing technical standards on collateral at CCPs. That process should be designed to allow sufficient time for ESMA to make a decision, with full consultation of those operating and using CCPs. ${ }^{14}$

ISDA thus fully accepted ESMA's authority to develop the technical standards autonomously. At the same time, however, it strongly encouraged ESMA to 
consult with market participants, and therefore implicitly with ISDA itself. In the policy documents exchanged with the European authorities, ISDA is always unequivocally positive regarding ESMA's role in the new regulatory framework. Between the lines, however, ISDA has also consistently been advocating a containment of the scope of EMIR (Biggins and Scott 2012; Helleiner et al. 2018).

Despite the fact that the various consultation and policy papers released by ISDA on EMIR mostly regarded technical details of the legislation, they also latently pertained to political disputes on the reach of public regulation. For example, when asked for its opinion on the applicability of EMIR to counterparties located in a third (non-EU) country, ISDA underlined the importance of having cooperation among jurisdictions in order to "avoid duplication and uncertainty over clearing obligations, and their application regionally". ${ }^{15}$ At the same time, ISDA advocated "that a branch or affiliate, based in a third country, of an EMIR-regulated firm dealing with another entity in that third country" $" 16$ should not be subject to EMIR, as this would increase the costs of providing its financial services in the country in which it operates. While on the one hand ISDA favoured international convergence in regulation, at the same time it also tried to influence the content and implementation of the new regulation to favour market participants. With this goal, ISDA also tried - and succeeded - to co-define together with ESMA the reach of the new central clearing obligations.

Even though it repeatedly expressed support for strengthening ESMA's authority and extending central clearing obligations in all the policy documents released between 2009 and 2018, ISDA was also very keen to ensure that certain sections of the market remained sheltered from the new regulation (Morgan 2009; Biggins and Scott 2012). For instance, in the following passages taken from a response to the European Commission in 2018, ISDA confirmed its support for international convergence but opposed measures that would touch on the whole market:

ISDA advocates that EMIR reporting be aligned with similar regimes globally, EMIR should establish a market-wide principle that derivatives transactions, which have been matched via confirmation and reconciliation processes, should only be reported once to supervisors, by one party, not twice.

ISDA cautions against taking a one-size-fits-all approach in deciding on a standard which is to be used for many requirements across disparate product sets and by many different types of entities. ${ }^{17}$

In other words, ISDA consistently advocated for uniform criteria across jurisdictions, but against using uniform criteria in applying the new rules across the whole market. While sponsoring uniformity across the jurisdiction, ISDA 
advocated against a product-uniformity approach when defining the eligibility criteria for central clearing, underlining that some products are less suitable for clearing than others, and that forcing uniform clearing standards for diverse products could cause market disruptions.

In this policy advocacy, ISDA turned out to be considerably successful. EMIR, in fact, contains two main sources of exemption from the central clearing obligation. The first regards intragroup transactions which consist in OTC contracts established between counterparties that are part of the same group. These transactions still need to go through appropriate centralised risk evaluation, measurement and control procedures yet they are exempt from the obligation to exchange collateral, which, as we mention below, applies to other non-centrally-cleared transactions. The second source of exemption derives from the decisions that ESMA takes regarding clearing eligibility. Under EMIR, in fact, ESMA gains the authority to decide which classes of derivatives should meet the clearing obligation. Both these sources of exemption were explicitly advocated for by ISDA between 2009 and 2012. Intragroup transactions were defined as 'vital to the industry' and ISDA confirmed its advocacy for sheltering certain types of transactions from clearing obligations, as the following passage shows:

The intragroup transaction exemption (from clearing and/or bilateral margining) is vital to the industry. We appeal to ESMA to use the flexibility afforded it in the EMIR level 1 text to phase Regulatory Technical Standards addressing the exemption in such a way that market participants do not have to collateralise transactions while awaiting regulatory approval of exemptions. If this situation can be avoided - while ensuring regulatory review of validity of application for exemption - it will prevent the creation of a misleading and excessive snapshot of bilateral risk and will also avoid a needless drain of liquidity at a time when liquidity is scarce. We also believe that it would be sensible to grant the exemption for 'kinds' of intragroup transaction (e.g. between certain counterparties) and not on a case-by-case basis (which would seem very demanding for regulators). ${ }^{18}$

The passage is taken from a response to a discussion paper released by ESMA only a few months before EMIR was finally adopted by the EU legislature. In the same document, ISDA also confirms its support for ESMA's autonomy to decide on the exemptions and the reach of central clearing obligations:

We believe that any clearing obligation must be transparent, clear and publicly disclosed. Furthermore, ESMA should have the flexibility to change the parameters around clearing obligations if required to quickly respond as a result of global discussions and/or market conditions. Again, these changes should be transparent, clear and publicly disclosed. ${ }^{19}$ 
The 'parameters around the clearing obligations' are precisely the centre of gravity of the interactions between, on the one hand, public authorities stepping into the regulation of the OTC derivative markets and, on the other, ISDA promoting itself as an interlocutor providing sectoral expertise. Once the global financial crisis had changed the public regulators' views on the unregulated status of these markets, ISDA promoted itself as a supporter and an interlocutor for developing public regulation in the OTC derivative market. However, as public regulators needed sectoral expertise to define the reach of the new legislation, ISDA had an opportunity to advocate the sheltering of specific market segments, and so to keep these market segments under its own private regulatory regime.

In sum, when public regulators intervened in the regulation of OTC derivatives, ISDA did not oppose the introduction of central clearing and reporting obligations. On the contrary, in Europe it favoured the authority granted to ESMA about deciding the technical standards to which derivatives should be cleared and reported. In this sense, we can say that ISDA favoured a centralisation of rule-making in Europe $(H 8)$. As a result, the system of hybrid governance that emerged with the entry into force of EMIR has at least to some extent curbed the control that ISDA's private regulatory regime had over the derivatives market. Today, most derivatives are subject to reporting and central clearing obligations, and it is ESMA rather than ISDA that decides whether certain derivatives are exempt from such obligations. At the same time, however, ISDA still plays an important role in the decisions on these exemptions, as it assists ESMA in its decisions by providing sectoral expertise in defining eligibility criteria. As we will argue more extensively in the conclusion, it is through these channels of expertise-provision that we can expect ISDA to try to maximise its influence on the governance of the derivatives market and has thereby secured itself an important role in the new regulatory structure (H9).

\subsection{THE REGULATION OF MARKET ABUSES IN THE AIM}

\subsubsection{The Creation of a Privately Self-regulated Market}

Just as the emergence of the unregulated OTC derivatives market happened in conjunction with the rise of neoliberal ideas (Mügge 2011), the establishment of the AIM happened in line with the policy course that the British government was pursuing during the 1990 s, namely the adoption of 'light touch' regulations in order to promote capital-raising and economic growth (Financial Times 2009). In the following two decades, in turn, the AIM proved to be an important driver of British economic growth, and also after the global financial 
crisis. In 2015, for example, AIM-listed companies generated over 400,000 jobs in the UK and contributed more than $£ 14$ billion to national GDP. ${ }^{20}$ The flexibility provided by the AIM regulatory regime is thus not only beneficial to the companies it serves but it also generates revenue for the whole British economy. The AIM is thus not a market operating transnationally ${ }^{21}$ but it has a specific location and is an important driver of its host-country's economic performance.

Unlike the OTC derivative market, the AIM is not a market for a particular type of financial instrument but is instead an ad hoc-created market sphere with very flexible rules. As a submarket of the London Stock Exchange (LSE), the AIM was designed as an accessible venue for small companies to raise capital. Its enhanced accessibility is provided by the rules for companies to be listed on the AIM. These rules are in fact much softer and more flexible than those of the main market for initial public offerings. Companies wishing to join the LSE, in fact, need to meet certain criteria, such as providing annual accounts and being valued at $£ 700,000$ or more (Financial Times 2018). When a company does not or is not able to meet these criteria, it can seek to list itself on the AIM. The AIM rules are relatively few and companies are not necessarily obliged to comply with them. Furthermore, the AIM applies the comply-or-explain mode of financial supervision: if a company fails to comply with AIM's rules, it may simply provide an explanation of why it has failed to do so (Espenlaub et al. 2012).

While the AIM was mainly established to help small companies raise capital, it also provides investors with a number of advantages. Generally, investors are fascinated by cases of fast high returns generated by companies dealing in the latest trending businesses, which are largely present on the AIM (Financial Times 2015a). In addition, for investors based in the UK, the AIM provides important tax advantages, such as business property relief and wealth taxes more in general. ${ }^{22}$ As we shall see below, however, the rules and the performance of the AIM are at times also investor-unfriendly, in the sense that the rules fail to address malpractices and, often being provided with inaccurate information, inexperienced investors face a relatively high chance of incurring financial losses (Financial Times 2015b). At the same time, however, the shadiness of the AIM also provides investors with the advantage of being able to make trades without publicly disclosing their intentions, as they may be required to do on regulated exchanges. ${ }^{23}$

The rules governing the AIM are set by the LSE and are therefore private in nature. More precisely, in European regulatory terms the AIM falls within the category of multilateral trade facilities (MTFs), ${ }^{24}$ a term used to refer to markets which are run by either a regulated market (like the LSE) or an investment firm. This terminology was introduced in the European Markets in Financial Instruments Directive (MiFiD) of 2004, which charged Member 
States with the responsibility to ensure that firms or exchanges operating an MTF establish transparent rules. ${ }^{25}$ As operating an MTF is a regulated activity in the UK, the LSE's opening of the AIM was subject to authorisation by the Financial Conduct Authority (FCA), which is the authority regulating financial services in the UK. The AIM is therefore governed by the privately set rules of the LSE, which in turn was authorised to run the AIM by the British financial authority. This again confirms the insight that private self-regulation is reliant on at least some form of public recognition (Pistor 2013). At the same time, it also highlights that with this structure the LSE is the entity directly subject to national and European legislation, while the AIM operates under the shelter provided by the authority gained by the LSE.

The regulatory framework of the AIM is principle-based rather than rule-based, in the sense that market participants have extensive leeway to interpret and implement a basic set of principles (Espenlaub et al. 2012, p. 429). This system works mainly through the reputational capital that market players build over time. The main actors responsible for ensuring compliance with the market rules are the nominated advisors (Nomads), which follow firms listed in the AIM in their regulatory compliance. Firms listed in the AIM are obliged to be linked to one of the various (currently 34) Nomads, which in turn compete to provide services to as many firms as possible. Nomads are financial companies, including both large international consultation companies such as Deloitte and PricewaterhouseCoopers, and less well-known consultancy companies focusing on specific business areas such as alternative energy, mining or real estate.

In order to operate in the AIM, Nomads must first be approved by the LSE, to which they also remain accountable. The LSE thus delegates the responsibility of market supervision to the Nomads. If a company fails, for example, to comply with AIM regulations, the LSE will fine the Nomad which follows it. Nomads, in turn, can force listed companies to comply with the AIM rules by threatening to cease acting as advisors to them and thus forcing them to leave the AIM. Table 6.2 summarises the scheme whereby the LSE decides the eligibility criteria for becoming a Nomad, and the main responsibilities that the latter has towards the LSE.

In practice, however, a series of malpractices in relation to this regulatory arrangement have been documented (Financial Times 2015a). As Nomads not only often receive fees but also may invest in the companies they assist, a conflict of interest regularly emerges between their regulatory function and the earnings they make from assisting specific companies. The LSE relies on fines and sanctions to ensure that the regulatory arrangement works, a threat that has occasionally been implemented in cases in which Nomads and the companies they assist were not able to prove that they had not divulged misleading information. Nomads, in turn, have an incentive to maintain their reputational 
Table 6.2 Nomads: eligibility criteria and main responsibilities

\begin{tabular}{|c|c|}
\hline Eligibility criteria & Responsibilities \\
\hline $\begin{array}{l}\text { be a firm or company; } \\
\text { have practised corporate finance for at least the last } \\
\text { two years, with at least three relevant transactions; } \\
\text { employ at least four qualified executives; } \\
\text { be capable of being effectively supervised by the } \\
\text { Exchange; } \\
\text { have appropriate financial and non-financial } \\
\text { resources; } \\
\text { the Exchange is able to exercise discretion as to } \\
\text { the application and interpretation of the eligibility } \\
\text { criteria as it thinks fit. }\end{array}$ & $\begin{array}{l}\text { to assess the appropriateness of an applicant for the } \\
\text { AIM, or an existing AIM company when appointed } \\
\text { as its nominated adviser; } \\
\text { to advise and guide an AIM company on its } \\
\text { responsibilities under the AIM rules for companies, } \\
\text { both in respect of its admission and its continuing } \\
\text { obligations on an ongoing basis; } \\
\text { to liaise with the Exchange when requested to do } \\
\text { so by the Exchange or an AIM company for which } \\
\text { it acts; } \\
\text { to advise the Exchange as soon as practicable if it } \\
\text { believes that it or an AIM company has breached the } \\
\text { AIM Rules. }\end{array}$ \\
\hline
\end{tabular}

Source: $\quad$ London Stock Exchange, AIM Rules for Nominated Advisers, July 2018.

capital and to reduce the chances of an extension of oversight by the LSE and public authorities. Despite various cases of malpractice, sanctions were rarely applied throughout the 2000s (Gerakos et al. 2013). In response to these malpractices, in 2006 the LSE published a handbook containing the basic rules for Nomads. In addition to the responsibilities summarised in Table 6.2, the LSE also added a conflict of interest clause, stating that "a nominated adviser must not have, and must take care to avoid, the semblance of a conflict". ${ }^{26}$

The private regulatory regime of the AIM features both similarities and differences with respect to the case of the OTC derivative market. On the one hand, unlike the OTC derivative market, the AIM is not a market that developed out of the emergence of new financial instruments but was instead purposefully established by the LSE. Compared to the OTC derivative case, therefore, the AIM is a case presenting different drivers behind the establishment of a private regulatory regime, thus disconfirming our hypothesis about self-regulation developing together with new financial instruments (H8.1). In the case of the AIM, in fact, there was no particular new financial instrument. The rationale behind the establishment of the AIM was to help small companies to raise capital in financial markets. Listing on the stock exchange and compliance with public regulatory standards can, in fact, be burdensome, particularly for small companies. By creating an alternative market space within the LSE, it became possible for firms to be listed on a stock exchange while at the same time being sheltered from the reach of public regulation and the related compliance costs. In the case of the AIM, this shelter particularly served to escape from the obligations for stock exchange listing defined by European directives (Mendoza 2008, p. 296). 
On the other hand, the AIM case confirms our hypothesis about the propensity of private self-regulatory regimes to attract new members. Like the OTC derivative market, in fact, the AIM expanded rapidly. Having been established in 1995 with ten listed British companies, in 2005 the AIM listed more than 1400 companies, both national and international. Between 2004 and 2006, it grew even faster than NASDAQ, raising \$55 billion (Mendoza 2008, p. 284) and registering a peak of almost 1,700 listed companies. This number, however, started to gradually fall in the following years, and since 2015 the number of listed companies has been below 1,000 (see Figure 6.1).

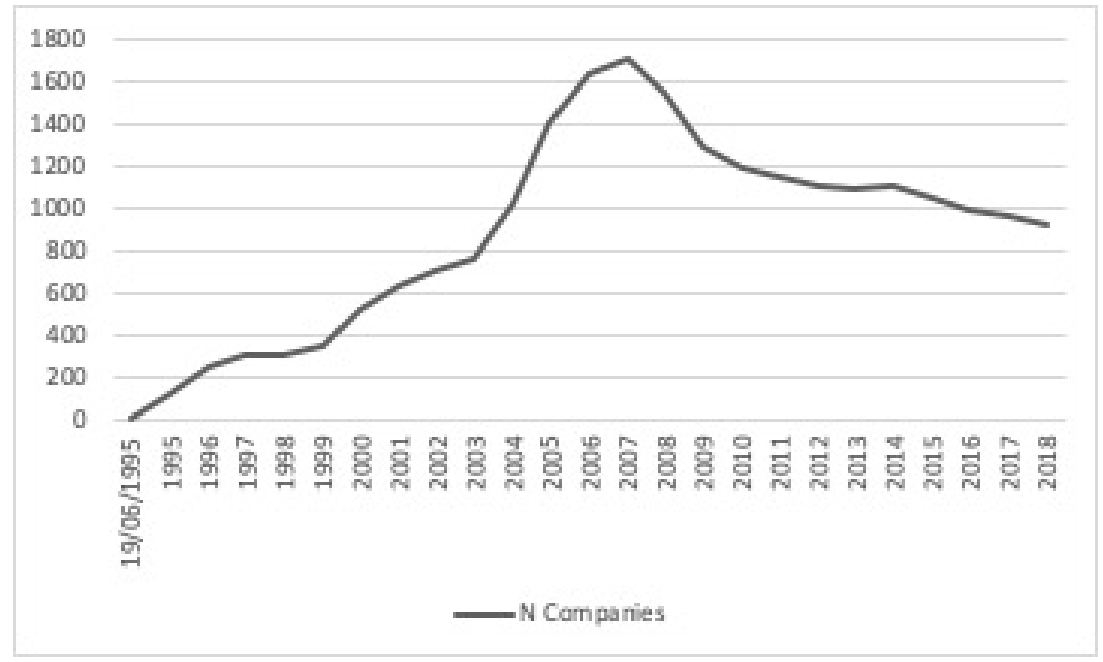

Source: London Stock Exchange data, https:/www.londonstockexchange.com/statistics/ historic/aim/aim.htm (accessed 27 March 2020).

Figure $6.1 \quad$ Number of listed companies in the AIM by year

This steady decline in the number of companies listed in the AIM and the market's consequent underperformance have attracted a wave of criticism of the functioning of its regulatory framework (Financial Times 2017). New light has also been increasingly shed on the overall performance of the AIM in generating returns for investors. While it fascinated investors with cases of fast high returns particularly in the first half of the 2000s, the 20-year record reveals more a story of substantial losses on the part of investors, particularly inexperienced ones who became the victims of misleading information and of the conflict of interests between the Nomads' regulatory function and their relations with listed companies (Financial Times 2015a). Even though this 
underperformance needs to be contextualised against the performance of other markets during these years (Stringham and Chen 2012), these criticisms also triggered the attention of public regulators which have an interest in protecting investors (Gerakos et al. 2013, p. 190).

\subsubsection{Public Intervention in an Investor-Unfriendly Market}

According to some studies, around 70 per cent of the companies listed on the AIM between 1995 and 2015 caused their investors losses (Dimson et al. 2015; Financial Times 2015b). In about a third of these cases, the loss caused by the company amounted to about 95 per cent of the initial investment. Surprisingly, however, not only is there no evidence of substantial action between 1995 and 2015 on structural problems but the LSE was actually found to be acting against efforts by public regulators to make the AIM subject to tougher regulation. More specifically, when in 2013 the British parliament was discussing the Financial Services Bill - which would assign more responsibilities for protecting investors to the FCA - the LSE tried to water down these efforts. ${ }^{27}$ Nonetheless, as the LSE was the actor responsible to public authorities for the functioning of the AIM, it came under increased pressure to demonstrate it was tackling malpractices. In parallel, EU legislation was about to expand towards including MTFs, and therefore also the AIM.

In July 2016, the AIM-listed companies became subject to new European legislation. The Market Abuse Regulation (MAR) extended the range of financial instruments covered by EU legislation and also reached out to instruments traded on MTFs. This regulatory approach was confirmed in the renewed version of MiFiD - MiFiD II - which entered into force in January 2018. Under this new regulatory framework, AIM-listed companies are directly subject to EU legislation which obliges them to disclose inside information to the public and to keep that information available for five years. The AIM, in turn, has also been working to adapt its internal rules and to establish new requirements for its listed companies. ${ }^{28}$ With the entry into force of first MAR and then MiFiD II, there has therefore been public regulatory intervention in the regulation of the AIM, as AIM-listed companies found guilty of market abuses are no longer fully sheltered by the LSE's private regulatory framework but are directly subject to public legislation. The question, however, is what will happen after the UK leaves the EU? While answering this question goes beyond the scope of this chapter, the process through which MAR was developed may offer some hints.

Similarly to the case of the HFT provisions discussed in Chapter 2, to develop MAR the EU also largely relied on pre-existing national frameworks, taking them from the Member States in which such regulatory frameworks were more developed. As the malpractices of the AIM had already caught the 
attention of British regulators in the 2000s, Britain had developed a framework for tackling abuses taking place in privately regulated trading facilities (Morgan Lewis 2016). First through the Market Abuse Directive (MAD) of 2003 and then through MAR, the British market-abuse framework was largely incorporated in EU legislation, under which national supervisory authorities like the FCA obtained more leverage to sanction market abuses occurring in MTFs. To some extent, while MAR extends the reach of national and European regulators to previously sheltered markets like the AIM, at the same time it features a certain continuity with previously existing legislation. According to some observers (e.g. Morgan Lewis 2016) this continuity offers reasons to believe that - whatever the post-Brexit scenario may be - there will be no rolling back of the current regulatory regime.

Similarly to the case of EMIR, with the MAR the EU regulators also seek to render the organisation requirements of MTFs more similar to those for regulated exchanges. The general aim of the legislation is therefore to extend European public oversight by increasing the amount of information that market participants are required to publicly disclose. The legislation therefore largely keeps in place the existing private regulatory regime but requires more transparency regarding what happens within it. The new rules not only apply to the companies listed in the MTF but also to the actors responsible for its internal regulation. Under MiFiD II, in fact, MTFs are also obliged to set up specific arrangements to address conflicts of interests. In the case of the AIM, this meant both introducing a new rule for listed companies to publish a website disclosing information about their business and organisation and new rules for the AIM about disclosing any potential conflicts of interests. ${ }^{29}$

While the scope of MAR is arguably too big to simply consider it a response to the underperformance of the AIM, at the same time its overall objectives were to enhance investor protection, reduce the risks related to disorderly markets, reduce systemic risks, improve efficiency and reduce the risk of unnecessary costs for market participants. ${ }^{30}$ The new direct subjection of AIM-listed companies to EU disclosure requirements and the responsibilities of the AIM to address potential conflicts of interest are therefore aimed at these objectives. In the new regulatory configuration, the FCA is charged with the responsibility to develop rules for disclosure with which AIM companies must comply. The FCA, in turn, develops these rules on the basis of technical standards and guidelines issued by ESMA. Therefore, the new European regulatory framework for MTF resembles the centralised structure we previously described for the OTC derivative market. At the same time, the new regulatory framework keeps the existing private regulatory regime in place. The AIM thus remains a self-regulated subset of the LSE - with Nomads still acting as key players in the regime - but with more direct surveillance by the FCA, which must ensure that the European disclosure rules are being followed. Therefore, 
the AIM case is in line with our argument that private self-regulation prompts a centralisation of rule-making, creating a mix of public-private governance in which the public regulator adds a few additional rules to existing regulatory regimes.

While the available evidence is arguably too thin to fully test our hypotheses on public intervention (H8.3 and H8.4), the case study does allow us to say something about the mechanisms driving public intervention. First, the AIM case probes the plausibility of the idea that widespread malpractices do trigger the attention of public regulators and so increase the possibility of them intervening. The pattern that seems to emerge out of the AIM case, in fact, is that the flaws in the private regulatory regime were widely known already in the 2000s, but pressure for reform only increased when the overall performance of the market started to deteriorate and so cases of malpractice became more disputed. Second, even though the AIM does not bear a systemic risk comparable to that of the OTC derivative market, the objective behind European regulation of MTFs was to reduce the possibility of systemic risk.

\subsection{HYBRID GOVERNANCE AND CENTRALISED RULE-MAKING}

The two cases analysed in this chapter tell the story of new European rules entering two spheres of the financial markets that were previously almost entirely privately self-regulated (although in the last instance relying on law to enforce contracts). Even though the two cases differ in nature - with OTC derivatives being a global transnational market and the AIM a submarket of the LSE - they share similar patterns of the public regulator stepping into private regimes. In both cases, in fact, the European public regulator intervened by adding new rules to the existing regime. As the new rules are valid for the whole European jurisdiction, in both cases we can speak of a centralisation of rule-making. The general idea set out in Chapter 1 (H8), therefore, finds corroboration in our two case studies, as in both cases the failures of the private self-regulatory regimes to tackle systemic risk and excessive rent-seeking prompted intervention. More precisely, in the case of OTC derivatives ISDA favoured the allocation of decision-making authority to European institutions, while in the case of the AIM the new public regulation continues to largely rely on the supervisory responsibilities of the Nomads.

Consequently, in both cases the hybrid regimes maintain important levels of continuity with the previous private regulatory structures. In the case of the OTC derivatives market, the Master Agreement still constitutes an important source of contractual standards and ISDA is still a regulatory reference point. In the case of the AIM, the controversial regulatory regime in which Nomads play a central role is also still in place. What has changed is that transactions 
happening in these markets are now directly subject to European regulatory requirements, with a few exceptions for OTC derivatives, where a segment of the market is still exempt from public regulation. Public regulators have therefore stepped in by increasing the scope of their market surveillance while at the same time keeping the regulatory structure in place. The centralisation thus mainly consists in certain regulatory standards being defined at the European level (Quaglia 2012). Whether this will also lead to a centralised governance of the markets, however, is still an open question as - as is also discussed in Chapter 2 - different member states have different traditions in carrying out market surveillance (Helleiner 2014).

Together with the case studies presented in Chapter 2, the two hybrid regimes discussed in this chapter confirm a general pattern emerging from the EU's financial regulation strategy. As has for example also been seen in the case study on high-frequency trading (Chapter 2), for the OTC derivative market and MTFs the strategy of the EU is to improve regulation by increasing the reporting obligations on market participants. The centralisation of rule-making is thus mainly about creating uniformity in the standards to which information should be disclosed. In this task, ESMA plays a key role, as it defines the standards with which firms operating in the European jurisdiction must comply. These standards define what should and what need not be reported to the public authorities. As we have seen, however, in defining such standards ESMA acts in close cooperation with private organisations, which are particularly keen to provide advice on the viability (and non-viability) of subjecting certain financial products to reporting requirements. In the aftermath of the global financial crisis, therefore, ISDA managed to secure itself an important role in the new European regulatory structure $(H 9)$.

While the general hypothesis about private self-regulation prompting public regulation finds corroboration in both case studies, a more complex argument needs to be developed for our hypotheses regarding the conditions under which private regulatory regimes emerge and develop (H8.1 and H8.2). On the one hand, the idea that private regimes will attract new members and that these will adapt to the existing regulatory structure (H8.2) seems to be highly plausible. In the case of OTC derivatives, in fact, since the 1980s the market has been attracting an exponentially increasing number of participants, all of whom either complied with ISDA's private regulatory regime or even became members of ISDA. Similarly, the AIM quickly grew from having ten listed companies in 1995 to listing over 1,000 companies during the 2000s, all of which were complying with the private regime put in place by the LSE.

On the other hand, our hypothesis about the emergence of private regulatory regimes (H8.1) is confirmed as plausible in the first case study but inaccurate in the second. In the first case, even though the trading of derivatives is a practice dating back a few hundred years, the emergence of ISDA's private 
regulatory authority during the 1980 s can be considered to be strongly related to the growing technological complexity of OTC derivatives, which made these instruments somewhat 'new' and difficult to standardise. As a result, the main market participants joined forces and established a private organisation - ISDA - which became the main regulatory authority in the market for these instruments. In a way, therefore, it can be said that ISDA's private regulatory regime emerged in relation to the emergence of 'new' financial instruments.

However, unlike the expectations set out in Chapter 1, the second case study on the AIM shows that private regulatory regimes do not necessarily emerge in relation to new financial instruments but may actually be purposefully created by private actors in order to avoid existing public regulation. In fact, the AIM was established to allow small companies to circumvent the costs related to compliance with public regulation and to provide a venue for investors in which they have lighter information disclosure burdens. The regime regulating the AIM was therefore not established to regulate the trading of a new instrument but simply to regulate a newly established venue.

This requires us to refine our theoretical argument about the emergence of private regulatory regimes by taking into consideration the incentives that private actors have to avoid public regulation. Both the extensive use of new financial instruments and the purposeful establishment of an alternative market can be seen as efforts to circumvent public regulation. The consequent formation of a privately self-regulated regime, in turn, can be seen as an effort to further structure and systematise this sheltering from public regulation. The theoretical framework set out in Chapter 1, therefore, needs to be refined in terms of the conditions under which market participants succeed in avoiding existing public regulation and the incentives they have to systematise such practices with a private regulatory regime. In sum, to understand the emergence and development of private regulatory regimes, a further reflection is needed on the drivers behind the actions of private actors in financial markets.

While our expectations about how private regulatory regimes emerge have turned out to be partially disconfirmed, our theoretical arguments about what drives public intervention instead seem to be highly accurate. Our hypotheses about the conditions under which public regulators step into private regulatory regimes (H8.3 and H8.4) are largely in line with the developments discussed in the two case studies. In both cases, the timing of public regulation is in line with the idea that either excessive rent-seeking or systemic risk plays a prominent role in decisions by public authorities to introduce new legislation. In the case of the OTC derivative market, in fact, the global financial crisis was the main trigger for public intervention. In the case of the AIM, recurring malpractices and the many losses incurred by various investors have kept the market under the attention of public regulators since the mid-2000s. However, 
in this latter case, strong public intervention only happened in the context of the broader European legislative initiative of MiFID II.

The difference in the timing of public intervention between the two cases can arguably be explained by the different systemic risk that the two markets bear, with OTC derivatives being the 'world's biggest market' (Helleiner et al. 2018) and the AIM being a submarket of the LSE. The systemic risk borne by the OTC derivative market became a central subject of public debate and among policymakers with the outbreak of the global financial crisis in 2008 . As a result of the large systemic risk perceived, actions by public regulators were almost immediate, as by 2012 in both the EU and the USA the OTC derivate markets were subject to central clearing and reporting requirements. The AIM, on the other hand, as a submarket of the LSE, bears considerably less systemic risk. Consequently, despite widespread malpractices, intervention by public regulators has been relatively slower.

The final lesson that can be drawn from these two case studies is that private actors are not by definition against a centralisation of rule-making. On the contrary, especially if they operate transnationally, they tend to be in favour of homogenous rules across different jurisdictions. At the same time, private actors may be very keen to shelter particular segments of the market from public regulation. It is on this front that the main struggle between public and private regulation within the EU is currently being fought: who gets control over what. In the process of uploading regulatory competences from the national to the supranational level, therefore, private actors are not necessarily an obstacle but they are taking action in order to contain the reach of regulation. When regulatory competences move from the national to the supranational level, therefore, so does the struggle between private and public authorities.

\section{NOTES}

1. For an example of the recognition of ISDA's Master Agreement on the part of public regulators, see the following page on derivative documentation from the Corporate Finance Manual issued by the British government: https://www .gov.uk/hmrc-internal-manuals/corporate-finance-manual/cfm13100 (accessed 28 October 2019).

2. https://www.fsb.org/2018/11/fsb-publishes-2018-g-sib-list/ (accessed 28 October 2019).

3. G20 Leaders' Statement, The Pittsburgh Summit, 24-25 September 2009, Pittsburgh.

4. Benoît Couré, Member of the Executive Board of the ECB, Speech at joint Banque de France, Bank of England and ECB conference on OTC derivative reform, Paris, 11 September 2013.

5. Ibid note 4 .

6. Ibid note 4 . Italics in the original. 
7. Ibid note 3 .

8. See also this press release by the European Commission: https://europa.eu/rapid/ press-release_IP-19-848_en.htm (accessed 27 March 2020).

9. Keynote address of Steven Maijoor, Chair of ESMA, to the ISDA AGM, 13 April 2011.

10. Ibid note 9 .

11. See, for example, ISDA, Letter sent to Timothy Geithner, President of the Federal Reserve Bank of New York, 31 October 2008, https://www.isda.org/a/PxoEE/Fed -Letter-Final10-31-08.pdf (accessed 27 March 2020).

12. E.g. ISDA Commentary on Indirect Clearing - Council Text of EMIR (29 July 2011). https://www.isda.org/category/public-policy/europe/ (accessed 30 October 2019).

13. E.g. ISDA, Comments on European Commission Consultation, 14 June 2010, https://www.isda.org/2010/06/14/isda-comments-on-european-commission -consultation-2/ (accessed 27 March 2020).

14. ISDA Comment Paper, A Prudent Approach to Collateral Requirements at CCPs, 29 July 2011, https://www.isda.org/a/zsiDE/02-isda-afme-collateral-at-ccps-jul -201-isda-comment.pdf (accessed 27 March 2020).

15. ISDA, Response to first ESMA discussion paper (dated 16 February 2012), Draft Technical Standards for the Regulation on OTC Derivatives, CCPs and Trade Repositories, 21 March 2012, https://www.isda.org/2012/03/21/isda-afme-bba -response-to-first-esma-discussion-paper-on-emir/ (accessed 27 March 2020).

16. Ibid (note 16).

17. ISDA Responds to EC's Supervisory Reporting Requirements 'Fitness Check', 21 March 2018, https://www.isda.org/2018/03/21/isda-responds-to-ecs-supervisory -reporting-requirements-fitness-check/ (accessed 27 March 2020).

18. ISDA, Response to first ESMA discussion paper (dated 16 February 2012), Draft Technical Standards for the Regulation on OTC Derivatives, CCPs and Trade Repositories, 21 March 2012, https://www.isda.org/2012/03/21/isda-afme-bba -response-to-first-esma-discussion-paper-on-emir/ (accessed 27 March 2020).

19. Ibid (note 19).

20. Grant Thornton, 'Economic Impact of AIM', April 2015, https://www .londonstockexchange.com/companies-and-advisors/aim/publications/ documents/gteconomicimpactofaim2015.pdf (accessed 27 March 2020).

21. Even though it has been attracting an increasing number of international investors (Financial Times 2015a; 2015b; 2018).

22. Source: London Stock Exchange, 'A guide to AIM tax benefits,' October 2015, https://www.londonstockexchange.com/companies-and-advisors/aim/ publications/aimuktaxguide.pdf (accessed 27 March 2020).

23. Source: Investopedia, https://www.investopedia.com/terms/a/alternative -investment-market.asp (accessed 27 March 2020).

24. See HMRC internal manual, Stamp Taxes on Shares Manual: https://www.gov .uk/hmrc-internal-manuals/stamp-taxes-shares-manual/stsm123050 (accessed 5 March 2019).

25. Article 14, Directive 2004/39/EC of the European Parliament and of the Council of 21 April 2004.

26. London Stock Exchange, AIM Rules for Nominated Advisers, July 2018, page 11.

27. RAID (Rights and Accountability in Development) Report, 'Asset laundering and AIM: Congo, corporate misconduct and the market value of human rights,' July 2012. 
28. Source: Burges Salmon, Briefing 'AIM companies dealing with inside information,' 23 June 2016, https://www.raid-uk.org/sites/default/files/aim-report.pdf (accessed 27 March 2020).

29. Financial Conduct Authority, https://www.fca.org.uk/mifid-ii/3-multilateral -trading-facilities-mtfs (accessed 27 March 2020).

30. Financial Conduct Authority, https://www.fca.org.uk/mifid-ii/1-overview (accessed 21 December 2019).

\section{BIBLIOGRAPHY}

Awrey, D. (2010). 'The dynamics of OTC derivatives regulation: bridging the publicprivate divide,' European Business Law Organization Review, 11, 155-193.

Biggins, J. and Scott, C. (2012). 'Public-private relations in a transnational private regulatory regime: ISDA, the state and OTC derivatives market reform,' European Business Organization Law Review (EBOR), 13(3), 309-346.

Bowman, A., Froud, J., Johal, S. and Williams, K. (2017). 'Trade associations, narrative and elite power,' Theory, Culture \& Society, 34(5-6), 103-126.

Dimson, E., Marsh, P. and Staunton, M. (2015). Global Investment Returns Sourcebook, Zurich: Credit Suisse Research Institute.

Engelen, E. (2017). 'Shadow banking after the crisis: the Dutch case,' Theory, Culture \& Society, 34(5-6), 53-75.

Espenlaub, S., Khurshed, A. and Mohamed, A. (2012). 'IPO survival in a reputational market,' Journal of Business Finance \& Accounting, 39(3-4), 427-463.

Financial Times (2009). 'Turner to end light-touch regulation,' 19 March.

Financial Times (2015a). 'AIM - 20 years of a few winners and many losers,' 19 June.

Financial Times (2015b). 'Aim is more miss than hit for investors as it marks 20th anniversary,' 19 June.

Financial Times (2017). 'Aim's wild west reputation seems to be deserved,' 15 October.

Financial Times (2018). 'What is AIM and how does its regulation system work?' 10 May.

Flanagan, S.M. (2001). 'The rise of a trade association: group interactions within the International Swaps and Derivatives Association,' Harvard Negotiation Law Review, 6, 211-264.

Gerakos, J., Lang, M. and Maffett, M. (2013). 'Post-listing performance and private sector regulation: the experience of London's alternative investment market,' Journal of Accounting and Economics, 56(2-3), 189-215.

Helleiner, E. (2014). 'Towards cooperative decentralization? The post-crisis governance of global OTC derivatives'. In: Porter, T. (ed.) Transnational Financial Regulation after the Crisis, New York: Routledge: 132-153.

Helleiner, E., Pagliari, S. and Spagna, I. (eds) (2018). Governing the World's Biggest Market: The Politics of Derivatives Regulation After the 2008 Crisis, Oxford: Oxford University Press.

Lagna, A. (2016). 'Derivatives and the financialisation of the Italian state,' New Political Economy, 21(2), 167-186.

Mendoza, J.M. (2008). 'Securities regulation in low-tier listing venues: the rise of the alternative investment market,' Fordham Journal of Corporate and Financial Law, $13,257-328$. 
Morgan, G. (2008). 'Market formation and governance in international financial markets: the case of OTC derivatives,' Human Relations, 61(5), 637-660.

Morgan, G. (2009). 'Legitimacy in financial markets: credit default swaps in the current crisis,' Socio-Economic Review, 8(1), 17-45.

Morgan Lewis (2016). 'UK market abuse extends its reach: implications for market participants,' 11 July 2016, https://www.morganlewis.com/pubs/uk-market-abuse -regime-extends-its-reach-implications-for-market-participants (accessed 27 March 2020).

Mügge, D. (2011). 'From pragmatism to dogmatism: European Union governance, policy paradigms and financial meltdown,' New Political Economy, 16(2), 185-206.

Pistor, K. (2013). 'A legal theory of finance,' Journal of Comparative Economics, 41(2), 315-330.

Quaglia, L. (2012). "The "old" and "new" politics of financial services regulation in the European Union,' New Political Economy, 17(4), 515-535.

Rauterberg, G. and Verstein, A. (2013). 'Assessing transnational private regulation of the OTC derivatives market: ISDA, the BBA and the future of financial reform,' Virginia Journal of International Law, 54(9), 9-50.

Schinasi, G., Craig, R.S., Drees, B. and Kramer, C. (2000). 'Modern banking and OTC derivatives markets,' Occasional Paper 2013, International Monetary Fund.

Stout, L.A. (2011). 'Derivatives and the legal origin of the 2008 credit crisis,' Harvard Business Law Review, 1, 1-38.

Stringham, E.P. and Chen, I. (2012). 'The alternative of private regulation: the London Stock Exchange's alternative investment market as a model,' Economic Affairs, 32(3), 37-43.

The Telegraph (2009). 'Bankers to receive huge bonuses despite financial crisis', 15 April. 